\title{
Population size and incidence of virus infection in free-living populations of Cucurbita pepo
}

\author{
Hector QUEMADA ${ }^{1,2 *}$, Laura STREHLOW ${ }^{1}$, Deena S. DECKER-WALTERS ${ }^{3,4}$ and Jack E. STAUB ${ }^{5,6}$ \\ 1 Department of Biological Sciences, Wood Hall, Western Michigan University Kalamazoo, MI 49008, USA \\ 2 Current address: Department of Biology, Calvin College, 1726 Knollcrest Circle, S.E., Grand Rapids, MI 49546, USA \\ 3 The Cucurbit Network, PO Box 560483, Miami, FL 33256, USA \\ 4 Current address: 5305 Mail Creek Lane, Fort Collins, CO 80525, USA \\ 5 USDA/ARS, Vegetable Crops Research Unit, Department of Horticulture, 1575 Linden Drive, University of Wisconsin, Madison, \\ WI 53706, USA \\ ${ }^{6}$ Current address: USDA, ARS, NPA, Forage and Range Research, Utah State University, 696 North 1100 East, Logan, UT 84322, USA
}

Impact assessments of virus resistance transgene introgression into wild, free-living populations are important for determining whether these transgenes present a risk to agriculture or the environment. Transgenic virusresistant Cucurbita pepo ssp. ovifera var. ovifera L. (squash) cultivars have been commercialized, and may be cultivated in close proximity to cross-compatible wild, free-living relatives (C. pepo subsp. pepo vars. ozarkana and texana). Therefore, the potential impact of these virus resistance transgenes was studied by surveying the incidence and fluctuations of virus infection (as assayed by ELISA), virus symptoms (which may not be seen in an infected plant) and population size in forty-three free-living C. pepo populations in Illinois, Missouri, Arkansas, Mississippi, Louisiana, and Texas. Ten of these populations were studied over three consecutive seasons. Depending on the year, $61 \%$ to $78 \%$ percent of the populations had at least one individual infected by at CMV, ZYMV or WMV2, but the median incidence of infection within populations was $13 \%$. The observed infection level in free-living populations was consistent with levels defined as "low" in field plot experiments conducted by others, leading to the conclusion that transgenic virus resistance should not provide a significant fitness advantage to the free-living populations examined. Viral symptoms were detected in only $2 \%$ of plants observed, indicating that severity of viral infection was low. CMV, ZYMV, and WMV2 were not the only viruses infecting these populations, further reducing the likelihood that resistance to these viruses would release populations from constraints imposed by virus diseases.

Keywords: transgenic / virus resistance / populations / Cucurbita pepo / introgression / gene flow

\section{INTRODUCTION}

Transgenic crop species have been commercialized since 1994, and are responsible for significant and demonstrable economic benefits in areas where they have been commercially adopted (Brookes and Barfoot, 2005, 2006; Sankula, 2006; Sankula and Blumenthal, 2004). Thus far, these crops have had a proven record of safety, both from a human/animal health and environmental perspective. Nevertheless, scientific issues surrounding the safety assessment of these crops continue to be of scientific interest. These continuing risk appraisals provide feedback for decision-making by testing the assumptions and conclusions made during the pre-market risk assessment, and thereby improve the quality, efficiency, and effectiveness

\footnotetext{
*Corresponding author: hdq2@calvin.edu
}

of the process used to assess the risk of transgenic crops. Post-market research may generate data that contradict the pre-market risk assessments, and therefore prompt a reconsideration of a previous regulatory decision, or may generate data that confirm those risk assessments and increases the level of confidence in regulatory decisions and approaches.

Of considerable ecological importance is the potential impact that transgenes might have on the structure and competitiveness of free-living (i.e. not agriculturally managed) populations into which they are introgressed. In the United States, several transgenic cultivars that have been commercialized or have received regulatory approval have been evaluated for these impacts, including rice, oilseed rape, squash, and cotton (USDA, 1994b, 1994c, 1994d, 1995a，1995b，1996b, 1996c, 1997a, 1997b, 1998a, 1998b, 1999a, 1999b, 


\section{H. Quemada et al.}

2002a, 2002b, 2002c, 2002d, 2003, 2004a, 2004b, 2005, 2006). Commercial transgenic squash has had the longest history of unrestricted regulatory approval, including approval for cultivation in areas where wild relatives may be present (USDA, 1994a). This regulatory approval was not without controversy, and was criticized in two reports written by the United States National Research Council (US National Research Council, 2000, 2002). Therefore, studies that provide further information regarding the potential impact of virus resistance transgenes in free-living populations have continuing relevance.

The deployment of transgenes in squash affords an opportunity to assess the risk of transgene flow from this crop given real patterns of commercialization and the proximity of transgenic cultivars to free-living populations. Commercialized transgenic squash cultivars express resistance to Cucumber mosaic virus (CMV), Zucchini yellow mosaic virus (ZYMV), and Watermelon mosaic virus 2 (WMV2) (USDA, 1996a) or only ZYMV and WMV2 (USDA, 1994a). Studies have shown that free-living Cucurbita pepo (C. pepo ssp. ovifera vars. ozarkana and texana) populations and cultivated squash (C. pepo ssp. ovifera vars. ovifera and pepo) can readily exchange genes (Chung 2006; Decker-Walters et al., 1993, 2002; Kirkpatrick and Wilson, 1988; Smith et al., 1992; Wilson, 1990). Moreover, transgenes from cultivars can be introgressed into wild genotypes without a significant decrease in fitness (Fuchs et al., 2004a, 2004b; Spencer and Snow, 2001). Consequently, the possible impact of virus resistant transgene introgression into freeliving squash populations continues to be an interesting area for investigation.

While methods for measuring gene flow have undergone extensive development for application in transgenic crops, the potential consequences of gene flow has not been well studied. The most information has been obtained for sunflowers (Arias and Rieseberg, 1994; Burke and Rieseberg, 2003; Linder et al., 1998; Pilson, 2000; Pilson and Decker, 2002; Reagon and Snow, 2006; Rieseberg et al., 1999; Snow et al., 1998, 2003; Whitton et al., 1997), and even in that system, the potential for negative consequences of transgene introgression into free-living populations has not been well established. The difficulties associated with defining such consequences include the inability to: (1) detect potentially small fitness differences during comparative analyses, and; (2) link observed fitness differences to weediness, invasiveness, or other long-term adverse environmental consequences.

With respect to C. pepo, Spencer and Snow (2001) suggested that given the demonstrated lack of barriers to transgene introgression into natural populations of C. pepo, it would be useful to document the frequency and severity of viral infections in free-living $C$. pepo populations in order to assist in determining whether a fitness-related trait such as transgenic virus resistance could enhance the abundance and invasiveness of this species. This approach is consistent with concepts elaborated by Hancock (2003), Pallett et al. (2004), and Raybould and Cooper (2005), who propose ways to assess the potential for transgenic traits to result in ecological release of wild relatives. For example, in the case of transgenes conferring pathogen resistance, which could increase fitness in wild populations, Hancock (2003) recommends that studies should be conducted to determine whether the level of control exerted by a pathogen on its host is significant. If a pathogen does exert significant control, then a gene conferring resistance to the pathogen could release the host from biological constraints that are preventing it from being weedy or invasive. This effect could be manifested by the appearance of larger or fastergrowing populations of squash containing the resistance trait, compared with populations of squash that do not have the resistance.

As implied by Spencer and Snow (2001), the extent to which pathogens (e.g., viruses) control free-living populations ought to be a function of infection incidence and severity. Therefore, the benefit of a resistance gene depends very much on what Fuchs et al. (2004a, 2004b) refer to as "virus pressure". Under conditions of "high virus pressure", i.e. $100 \%$ infection of plants in a population by day $32-42$ of the season, Fuchs et al. (2004a, 2004b) demonstrated that virus resistance transgenes in transgenic squash cultivars can indeed confer a selective advantage on wild genotypes. However, they detected no benefit under low disease pressure (less than $10 \%$ infection by day 32). While the selective advantage reported under substantial disease pressure may be expected to result in the increase in frequency of the virus resistance transgene within populations, virus pressure (incidence and severity) and its effect on population size is the focus of the present study, because it provides a better indicator of ecological release, which is of greater concern for regulatory purposes (Hancock, 2003; Pallett et al., 2004; Raybould and Cooper, 2005).

In support of a petition for the non-regulated status of transgenic virus resistant squash, nine free-living C. pepo populations were surveyed to assess the potential threat of transgene introgression (USDA, 1994a, 1994b). Although that survey failed to detect the presence of any viruses against which the transgenic squash crop was resistant, the number of populations examined was relatively small. Thus, the present study was designed to: (1) examine a larger number of wild $C$. pepo populations for the frequency of infection by WMV, ZYMV, CMV, and other viruses; (2) assess the severity of virus disease in infected plants as determined by the presence or absence of symptoms; and (3) to determine whether there is any relationship between the incidence of viral 


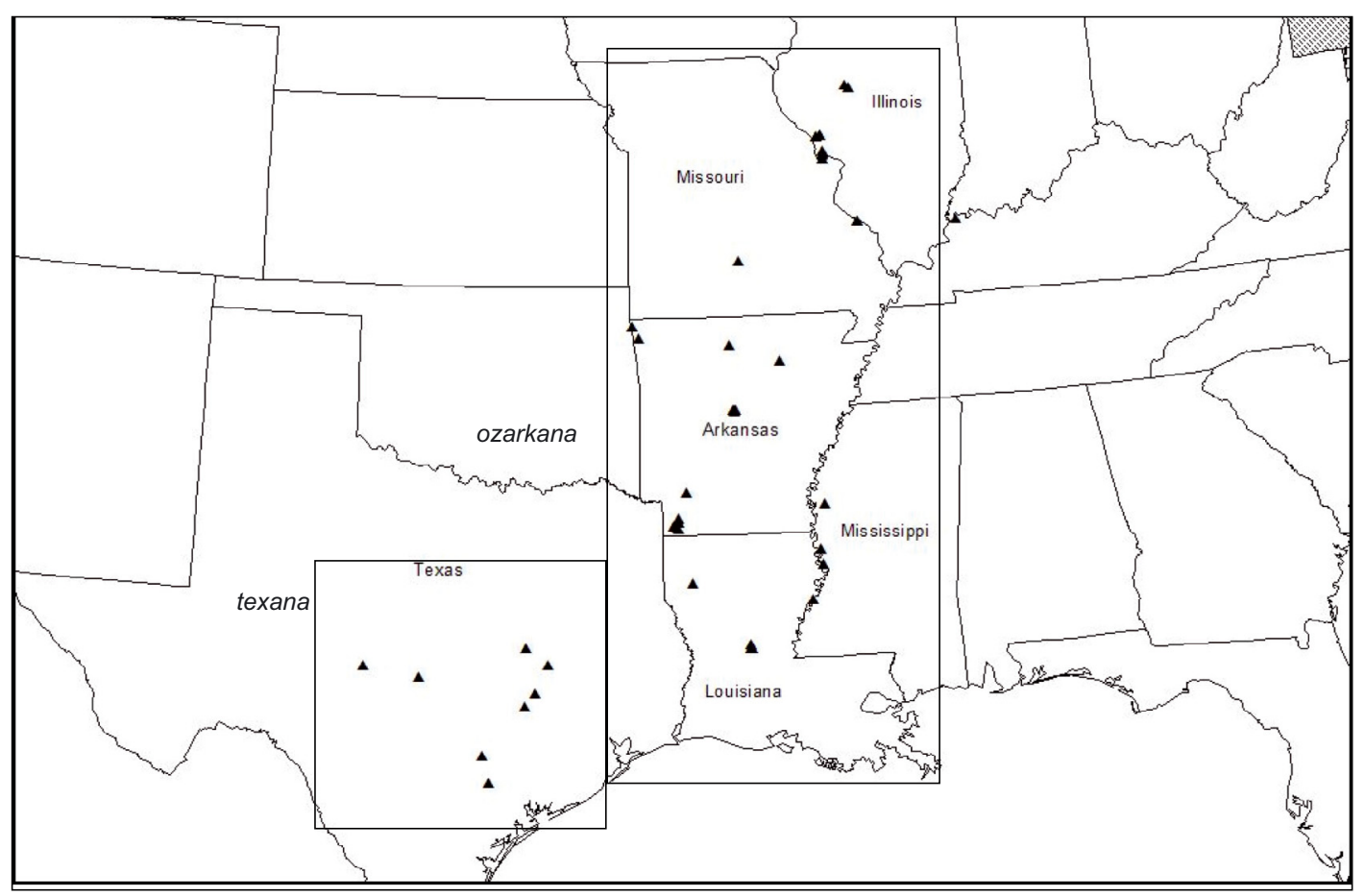

Figure 1. Locations of the C. pepo L. populations surveyed from 2000 through 2002. Populations of var. texana and ozarkana are delimited by boxes.

infection (determined by ELISA) within populations, and population levels in subsequent years. The occurrence of an infection may not have a significant impact on plant mortality or reproduction if symptoms are not expressed. Therefore, the incidence of visual symptoms in free-living populations was also recorded. The information obtained in this study can be linked to experimental studies of transgene flow and fitness in C. pepo, to determine which experimental conditions most closely reflect nature, and thereby to draw conclusions regarding the fitness advantage specific virus resistance transgenes might confer on free-living populations. Furthermore, the descriptive approach used in this study will likely be useful for risk assessments of similar interactions between other transgenic crops and their free-living sexually compatible relatives.

\section{RESULTS}

\section{Locations}

Forty-three C. pepo var. ozarkana and var. texana populations were surveyed for this study. The locations of these populations are shown in Figure 1. Free-living C. pepo populations were typically found in disturbed areas on river or irrigation canal banks, or in river floodplains. Many populations grew in or on the edges of agricultural fields (associated with soybean, maize, cotton, millet, wheat). A molecular marker examination by Chung et al. (2006) of a subset of the populations surveyed in this study provided evidence of introgression from cultivated squash. While Chung et al. (2006) did not determine the presence of transgenes, it is unlikely that any of the free-living populations we surveyed had crossed with transgenic cultivated squash, since these populations were not in the areas where most transgenic squash cultivation occurs (Sankula 2006; Sankula and Blumenthal, 2004). Furthermore, in the three years of surveys, we encountered only one field of transgenic squash. This field was $>50 \mathrm{~km}$ from the closest free-living population sampled by us or by Chung et al. (2006).

\section{Population size}

Forty-three populations (see Materials and Methods for the definition of "population") were surveyed through the 2000, 2001, and 2002 growing seasons, yielding 58 estimates of population size. These data are provided in Table 1, and the distribution of population sizes is shown in Figure 2. Excluding population 37 (not depicted 
Table 1. Population sample sizes, and virus infection of free-living C. pepo L. Populations indicated by shading were studied for three consecutive years.

\begin{tabular}{|c|c|c|c|c|c|c|c|c|c|}
\hline \multirow[b]{2}{*}{$\begin{array}{l}\text { Population } \\
\text { ID }\end{array}$} & \multicolumn{4}{|c|}{2000} & \multicolumn{4}{|c|}{2001} & \multirow{9}{*}{$\begin{array}{c}\mathbf{2 0 0 2} \\
\text { Number of } \\
\text { individuals }\end{array}$} \\
\hline & $\begin{array}{l}\text { Number of } \\
\text { individuals }\end{array}$ & $\begin{array}{l}\text { Individuals } \\
\text { assayed by } \\
\text { ELISA }\end{array}$ & $\begin{array}{l}\text { Proportion } \\
\text { CZW }\end{array}$ & $\begin{array}{l}\text { Proportion } \\
\text { PPCZW }\end{array}$ & $\begin{array}{l}\text { Number of } \\
\text { individuals }\end{array}$ & $\begin{array}{l}\text { Individuals } \\
\text { assayed by } \\
\text { ELISA }\end{array}$ & $\begin{array}{l}\text { Proportion } \\
\text { CZW }\end{array}$ & $\begin{array}{l}\text { Proportion } \\
\text { PPCZW }\end{array}$ & \\
\hline 1 & 2 & & & & & & & & \\
\hline 2 & 1 & & & & & & & & \\
\hline${ }^{2} 3$ & Not reported & 10 & 0.3 & 0.3 & & & & & \\
\hline${ }^{2} 4$ & Not reported & 10 & 0.9 & 0.9 & & & & & \\
\hline 5 & 13 & & & & & & & & \\
\hline 6 & 2 & & & & & & & & \\
\hline${ }^{2} 7$ & 25 & 10 & 0.3 & 0.5 & & & & & \\
\hline${ }^{1} 8$ & 5 & 2 & 0 & 0 & 30 & Not sampled & & & Not revisited \\
\hline${ }^{19} 9$ & 10 & 1 & 0 & 0 & 10 & & & & \\
\hline 10 & 300 & & & & 100 & & & & \\
\hline${ }^{2} 11$ & 30 & 9 & 0 & 0 & & & & & \\
\hline 12 & 30 & 8 & 0 & 0 & & & & & \\
\hline 13 & 1 & & & & & & & & \\
\hline 14 & 5 & & & & 15 & 12 & 0.58 & 0.58 & \\
\hline 15 & 2 & & & & 30 & 10 & 0.4 & 0.4 & \\
\hline 16 & 19 & 19 & 0.47 & 0.47 & & & & & \\
\hline 17 & 3 & 3 & 0.67 & 1 & & & & & \\
\hline 18 & 51 & 32 & 0.84 & 0.88 & & & & & \\
\hline 19 & 7 & 7 & 0.43 & 0.71 & 21 & Not sampled & & & Not revisited \\
\hline 20 & 6 & & & & & & & & \\
\hline 21 & 2 & & & & & & & & \\
\hline 22 & 5 & & & & & & & & \\
\hline 23 & & & & & 2 & 2 & 1 & 1 & \\
\hline 24 & 5 & & & & & & & & \\
\hline 25 & 200 & 64 & 0.5 & 0.78 & & & & & \\
\hline 26 & 2 & & & & & & & & \\
\hline 27 & 2 & 2 & 0 & 0 & & & & & \\
\hline 28 & 1 & 1 & 0 & 1 & & & & & \\
\hline 29 & 46 & 46 & 0.52 & 0.76 & & & & & \\
\hline 30 & 25 & 25 & 0.24 & 0.64 & & & & & \\
\hline 31 & 9 & 9 & 0.22 & 0.89 & & & & & \\
\hline${ }^{1} 32$ & 13 & 3 & 0.33 & 0.67 & & & & & \\
\hline 33 & & & & & 60 & 16 & 0.06 & 0.06 & \\
\hline 34 & 21 & 21 & 0 & 0 & 15 & 15 & 0.4 & 0.47 & 4 \\
\hline 35 & 16 & 15 & 0.13 & 0.47 & 0 & & & & 6 \\
\hline 36 & 23 & 23 & 0.13 & 0.13 & 0 & & & & 0 \\
\hline 37 & 10000 & 32 & 0 & 0.25 & 0 & & & & 5 \\
\hline 38 & 40 & 19 & 0.05 & 0.37 & 0 & & & & 2 \\
\hline 39 & 5 & 5 & 0 & 0 & 6 & 6 & 0.5 & 0.5 & 5 \\
\hline 40 & 35 & 10 & 0 & 0 & 7 & 7 & 0.14 & 0.29 & 13 \\
\hline 41 & 12 & 9 & 0 & 0 & 7 & 7 & 0 & 0 & 9 \\
\hline${ }^{1} 42$ & 42 & 3 & 0 & 0 & 6 & 6 & 0 & 0 & \\
\hline${ }^{1} 43$ & 29 & 2 & 0 & 0 & & & & & \\
\hline
\end{tabular}

${ }^{1}$ Included in the analysis of population size but not in the analysis of virus incidence for 2000 (see Materials and Methods).

${ }^{2}$ Collected by Dr. Amanda Neill, Botanical Research Institute of Texas. Population size was estimated by visual appraisal. 


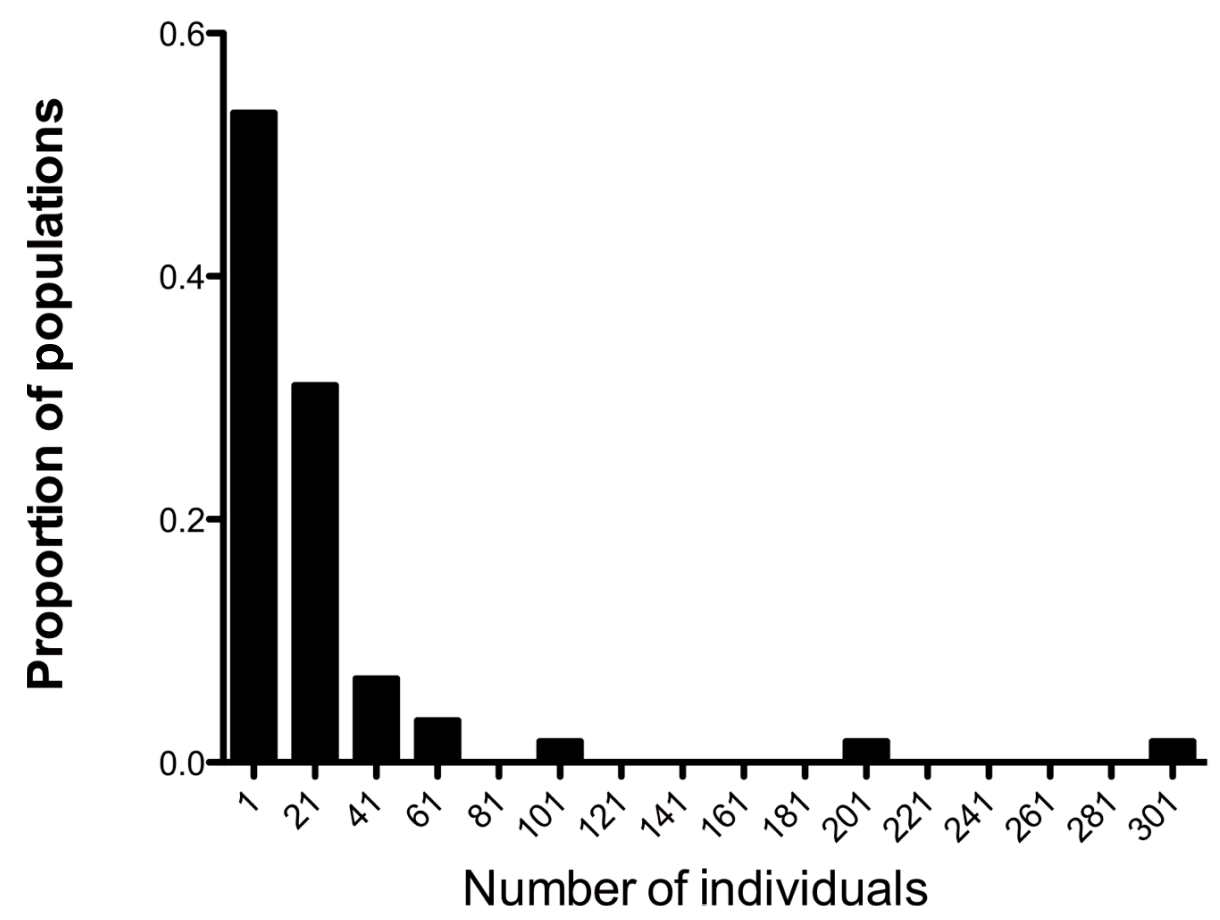

Figure 2. The distribution of population sizes of free-living C. pepo L. surveyed for this study, excluding population 37.

in Fig. 2), free-living C. pepo populations were relatively small, with a median number of 10 . Only four of the populations consisted of more than 100 individuals. These small populations were an indication that freeliving $C$. pepo may not present as much of a weed problem as they have in the past (Boyette et al., 1984; Bridges, 1992).

\section{Rates and patterns of infection in natural populations}

The number of samples and plants infected with CMV, WMV2, and ZYMV either singly or in combination are also given in Table 1. The numbers of plants infected by these three viruses, in addition to papaya ringspot virus (PRSV) and other unidentified potyviruses are also presented therein. For the populations surveyed and sampled in 2000 and for which data were included for analysis (see Materials and Methods), sixty-one percent (14 out of 23) populations contained at least one individual infected by at least one of the viruses for which transgenic resistance has been developed (CMV, ZYMV, or WMV2). If PRSV and other potyviruses are considered in addition to these viruses, $70 \%$ of populations were infected. For the populations that were re-surveyed and re-sampled in $2001,78 \%$ of populations were infected with the viruses assayed.
The distribution of virus incidence among populations in 2000 is shown in Figure 3, which illustrates the low incidence of virus infection within populations. Figure 3 shows that uninfected populations comprise the largest class, while $100 \%$ infected populations are rare. The median incidence of infection by CMV + ZYMV + WMV2 (CZW) is 0.13 , but was higher for PRSV + $\mathrm{ZYMV}+\mathrm{WMV} 2+$ other potyviruses (PPCZW) at 0.47 In 2001, the median incidence of infection for both CZW and PPCZW infections was 0.4. Because of the smaller number and more limited geography of populations assayed in 2001, it is not possible draw meaningful conclusions based on a comparison of virus infection in 2000 versus 2001. However, it is clear that other viruses against which no transgenic resistance has been deployed are also present in free-living populations, and may also exert an impact on these populations.

In contrast to the incidence of infected plants detected by ELISA, the incidence of symptomatic plants (by visual inspection of a total of approximately 11000 plants in 2000 and 2001 combined) was $2 \%$ over all locations. Therefore, the severity of virus infection in free-living populations was too low to elicit consistent detectable visual symptoms. As discussed in the following section, this lack of symptoms indicates that despite the detection of virus infection in free-living populations, the physiological impact of these infections is low, and therefore the impact on population levels is likely to be low as well. 


\section{H. Quemada et al.}

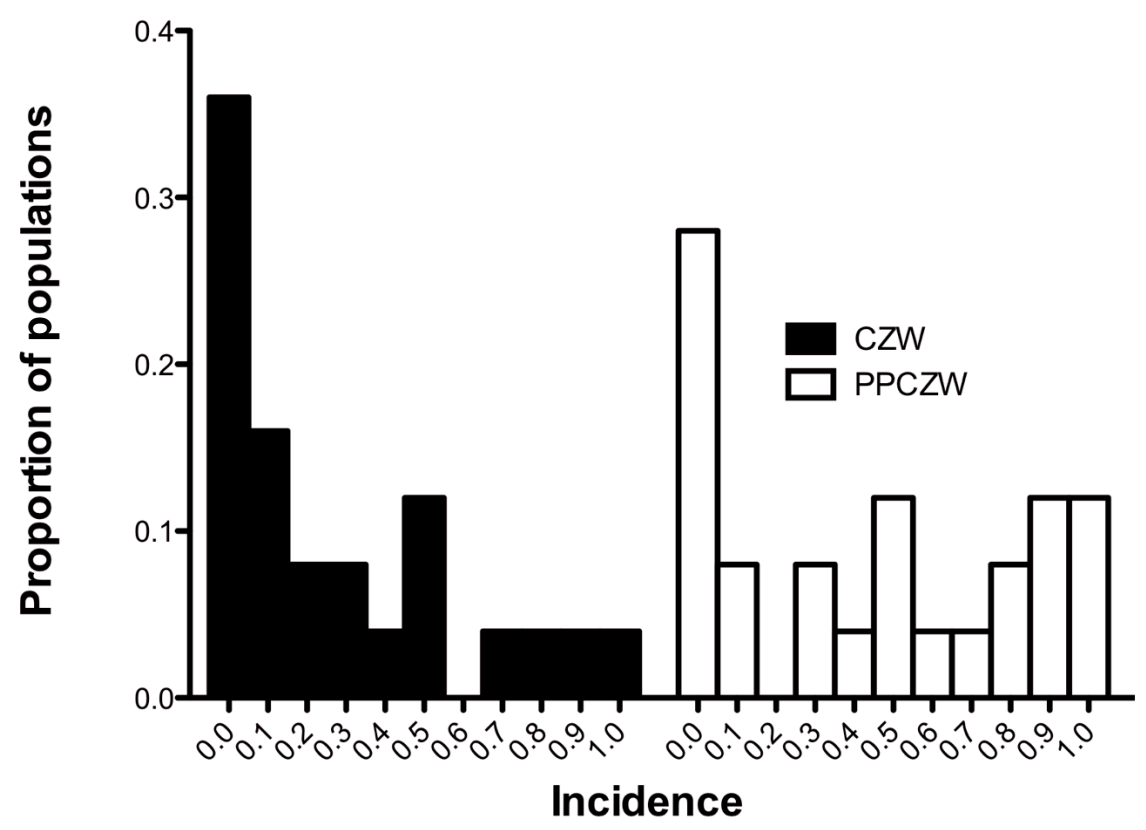

Figure 3. The distribution of virus incidence in $C$. pepo L. populations in 2000. Filled columns indicate the incidence of $\mathrm{CMV}+\mathrm{ZYMV}+\mathrm{WMV} 2$ infection, while unfilled columns indicate the incidence of all viruses assayed (Potyvirus $+\mathrm{PRSV}+\mathrm{CMV}+$ ZYMV + WMV2)

\section{Infection and population size in sequential years}

Population size and the incidence of virus infection varied greatly from year to year (Tab. 1). We were able to repeat surveys of a subset of populations over three years (indicated by shading in Tab. 1). Most of the populations (34 through 41), located near the Illinois and Mississippi rivers in Illinois and Missouri, decreased in size or remained constant over 2000, 2001 and 2002. In contrast, the size of two populations (population 8 in Louisiana and population 19 in Arkansas), increased from 2000 to 2001.

Examination of population size and virus incidence in Table 1 failed to reveal a discernable association between fluctuations in population size and the incidence of virus infections in the populations studied. Because of the relatively few populations followed over three seasons, meaningful statistical analyses of any correlations were not possible. Therefore the analysis presented here should be viewed as a starting point for more extensive surveys in the future. The very large data sets necessary to provide a rigorous test of correlations between virus infection and changes in populations will require a more significant effort than was possible within the resources available for this study.
Populations 34 through 41 declined from 2000 to 2001 in the absence of virus infection. Populations 34, 39, 40 , and 41 were infected in 2001 , but only population 34 showed a large decline in population number during the investigation period. Population 39 remained stable ( 5 to 6 individuals) despite the lack of infection in 2000 and a $50 \%$ incidence of infection in 2001. This population was reported to have remained stable at this level for at least 10 years prior to our survey (D. Asch, New York State Museum, personal communication, 2000). Although populations 35 through 38 were infected in 2000, and then were completely absent in 2001, this absence was due to conditions other than virus infection (see Discussion). The complete disappearance of population $37(n>$ 10000 ) is particularly interesting, given that only $25 \%$ of individuals were infected with viruses, including viruses other than CMV, ZYMV, or WMV2. ELISA assays detected primarily PRSV infections in this population, and one individual tested positive for an unidentified potyvirus. There was no obvious reason for this disappearance, since the site appeared undisturbed between 2000 and 2001. The presence of five individuals in population 37 in 2002 was clearly attributable to influx of new individuals rather than from the seed bank, since those individuals were found clustered around the remnants of a fruit that was found at the margin of a recently dried pool 
of water in the field. Free-living C. pepo fruits are waterdispersed (Smith et al., 1992). Arkansas population 19 trebled in number despite the relatively high level of virus infection present (43\% CMV + ZYMV + WMV2; 71\% Potyvirus + PRSV + CMV + ZYMV + WMV2). Lastly, population 8 increased in the absence of virus infection between 2000 and 2001. This population was the only one followed from year to year that showed the change expected if the viruses assayed in this study were restricting the size of these free-living populations.

\section{DISCUSSION}

Although the recent commercialization of numerous transgenic crops has provided many benefits for U.S. agriculture, continued research is needed to monitor the potential risks posed by the introduction of engineered traits into free-living relatives of these crops. Data presented herein identified free-living squash populations in the southern U.S. not previously described, in order to assess the potential impact of virus infection on these populations.

\section{Population survey}

Free-living C. pepo populations generally consist of relatively few individuals (median number $=10$ ). The present small size of free-living $C$. pepo populations suggests that this plant does not pose the same weed problem that it might have in the past. In the populations studied, the numbers of individuals varied from year to year (Tab. 1). However, we were not able to attribute the fluctuations in population size to virus infection, since no relationship could be discerned between the incidence of virus and the number of individuals in subsequent generations.

On the other hand, we were able to determine that the decline in the size of Illinois and Missouri populations 33 through 41 (Tab. 1) was associated with the agricultural practices employed in and around the fields where these populations were found. In particular populations 34 through 36 and 38, which disappeared in 2001, were in areas where evidence of weed control was observed (mowing or herbicide). Growers interviewed during the 2000 survey and sampling trip attributed the elimination of problems caused by "weedy gourds", a significant pest in fields previously planted with soybean and cotton, to the use of Roundup ${ }^{\circledR}$ herbicide. These observations were corroborated during a 2006 survey of free-living C. pepo populations in the central and southern U.S. (C. Calderon, University of Wisconsin-Madison, personal communication, 2006). Therefore, it is likely that agricultural weed control practices have a significant influence in limiting free-living $C$. pepo populations in agricultural settings.
Additionally, drought, herbivory (insects as well as mammals), and other diseases (bacteria and fungi) were also contributing factors identified during the 2000 survey trips that may also have influenced the size of free-living populations in the sites examined (data not presented).

\section{Impact of virus on population size}

In contrast to a previous survey conducted prior to the commercial release of transgenic squash (USDA, 1994b), the 2000 and 2001 surveys showed that free-living $C$. pepo plants are indeed infected by viruses (Tab. 1, Fig. 3). Given a median viral incidence of for CMV + ZYMV + WMV2 of 0.13 to 0.4 within populations, depending on the year, most plants in the populations examined would be expected to remain uninfected by these viruses, and thus should not benefit from introgressed virus resistance transgenes. Furthermore, the impact of virus infection on individuals that are infected may be affected by other environmental or evolutionary factors, since the incidence of virus infection was not a clear predictor of population increase or decrease in subsequent seasons (Tab. 1). The general dearth of individuals in most of the populations surveyed does not allow for a quantitative analysis of the impact of virus infection on population size. This was even more difficult for determining any correlation between the incidence of symptoms and changes in population size, which, due to the low incidence of symptomatic plants, could not be tested. However, for our dataset, fluctuations (or constancy) of population size cannot be qualitatively explained by the presence or absence of viruses. It is possible, however, that following more populations over a longer period of time would reveal patterns that our dataset did not enable us to detect.

We have considered the possibility that the reason for the low incidence of infection, especially in 2000, may be the result of a high infection rate at the seedling stage that then leads to the death of infected individuals before sampling. This explanation does not appear likely under natural conditions. Fuchs et al. (2004a, 2004b) showed that uninoculated seedlings of $C$. pepo did not show symptoms until at least 30 days post-planting. Spencer and Snow (2001) report the appearance of symptoms in C. pepo populations at day 45 post-planting, even though sources of inoculum were nearby. Furthermore, Klas et al. (2006) conducted experiments in which two $C$. pepo plots, each consisting of 200 plants, were planted as seedlings, surrounded by inoculated plants as a source of inoculum. Under this high level of virus disease pressure, 399 of the 400 plants survived to the end of the experiment (74 days post-planting). Therefore, it is not likely that seedlings are exposed to virus infection early in the season, and even if they were, survival rates would be high. 


\section{H. Quemada et al.}

If the apparent lack of control of populations by virus infection is corroborated by further study, this conclusion would not be surprising in light of the results of Fuchs et al. (2004b), who were only able to show a fitness benefit from viral transgenes under high disease pressure. That high level of disease pressure was not found in the natural settings observed in this study, confirming the opinion of Fuchs et al. (2004a) that high disease pressure is "unlikely to be consistently present throughout the United States, particularly in the Southern parts". Moreover, Spencer and Snow (2001) reported that even when viral symptoms are apparent and the leaf area of plants is greatly reduced by such infection, plants produced fruits with high quality seed in abundance. Consistent with this observation of Spencer and Snow (2001), our field impact assessment of introgressed transgenic virus resistance on fitness and fecundity in free-living C. pepo genotypes was not able to find a clear fitness benefit conferred by these transgenes (Strehlow and Quemada, data not presented, manuscript in preparation).

Disease levels found in the populations studied closely matches the low disease pressure conditions reported by Fuchs et al. (2004b) who evaluated the beneficial effects of transgenes in several wild $C$. pepo backgrounds. Fuchs et al. (2004b) achieved their low disease pressure (due to CMV, ZYMV or WMV2) by transplanting healthy plants to locations removed from sources of infection. Such a situation would be similar to that found in free-living $C$. pepo populations, because of the non-persistent mode of transmission (i.e., transmitted within minutes of acquisition by their aphid vector) of the viruses studied. Logically, non-persistent transmission requires that in each season, emerging seedlings must be re-infected from nearby infected plants. The small numbers of individuals in most free-living C. pepo populations, with intervening plants not susceptible to CMV, ZYMV, or WMV2, should therefore effectively isolate these populations from exposure to virus infection.

Low disease pressure in free-living C. pepo populations is also evidenced by the fact that only a few of the populations sampled were $90-100 \%$ infected by CMV + WMV2 + ZYMV (Tab. 1). At the life stage when most of the free-living plants in this study were sampled (i.e., probably more than six weeks post-germination), the high-disease pressure conditions imposed by Fuchs et al. (2004b) would likely have produced $100 \%$ infection, based on the disease progress reported by those researchers. Instead, the proportion of infected plants observed in this study is consistent with the level of infection under the low disease pressure conditions they described.

Low disease pressure experienced by natural C. pepo populations is further mitigated by the low severity of the infections detected. The incidence of symptomatic infections, compared to the incidence of infections detected by ELISA, is dramatically lower. The discrepancy between these numbers indicates that in populations studied, the physiological impact of caused by virus infection (and consequently the impact on fitness) is likely to be low. This expectation is supported by studies that have shown minor reductions in yield (presumably a good indicator of the physiological status of a plant) in C. pepo cultivars inoculated with a ZYMV strain that produces mild symptoms (Spence et al., 1996). Similarly, in another cucurbit, Cucumis melo, inoculation with a weak (symptomless) strain of ZYMV resulted in no reduction in yield compared with uninfected plants (Perring et al., 1995). Studies in tomato, with Tomato aspermy virus, have also shown only minor yield reductions in plants infected with a strain producing mild symptoms (Kuti and Moline, 1986). Therefore, it appears to be a general phenomenon that virus infections that do not produce symptoms also lack significant physiological impact on infected plants.

Analysis of the virus composition of the infected populations examined shows that PRSV and other potyviruses are detectable in free-living $C$. pepo populations (Tab. 1). There are no transgenes deployed against such viruses in commercial squash, and therefore, even if resistance to CMV, ZYMV and WMV2 were to benefit free living C. pepo, other cucurbit viruses such as PRSV and Squash mosaic virus (which we did not assay) would continue to affect these populations. These populations would also continue to be susceptible to other disease constraints, and abiotic stresses as well.

The opportunity for gene flow between squash and free-living populations has been demonstrated (Chung, 2006; Decker-Walters et al., 1993, 2002; Kirkpatrick and Wilson, 1988; Smith et al., 1992; Wilson, 1990). Therefore, there would be potential for introgression of transgenes into free-living $C$. pepo populations if there were an overlap with the areas where commercial transgenic crops are grown. Commercial adoption of virus resistant transgenic squash in 2001 and 2003 occurred primarily in Florida and Georgia (17 and 19\%, respectively; Sankula and Blumenthal, 2004). In 2006, however, transgenic, virus-resistant squash expanded, comprising 22, $20,5,25,10,20$, and $20 \%$ of the total planted acreage in Florida, Georgia, Michigan, New Jersey, North Carolina, South Carolina, and Tennessee, respectively (Sankula, 2006; Sankula and Blumenthal, 2004). While these states account for $70 \%$ of the U.S. commercial squash acreage (Sankula, 2006), they are not part of the reported geographic distribution of free-living C. pepo (Decker, 1988; Smith et al., 1992). Furthermore, the transgenic squash acreage in these states is relatively low (at most 25\%). Therefore the opportunity for gene flow between transgenic and free-living C. pepo populations is low. 
However, if the adoption of transgenic squash were to increase and spread to areas where gene flow to free living populations were more likely, then the information provided in this report regarding the potential interplay between virus resistance and population size in free-living $C$. pepo would strengthen existing assessments of risks associated with introgression of virus resistance transgenes. Data on the incidence and severity of virus infection do not support the hypothesis that introgressed virus resistance would release wild squash populations from restraints imposed by the presence of viral pathogens.

\section{MATERIALS AND METHODS}

\section{Virus surveys}

Surveys of free-living C. pepo populations were conducted in 2000, 2001, and 2002. Four hundred eightyone plants collected from 32 populations were assayed by ELISA for virus infection in 2000 and 2001. However, for some samplings, fewer than five individuals were taken. Consequently, unless the five or fewer samples represented the entire population surveyed, we excluded those data points from further analyses.

Areas explored for the presence of populations were determined by the study of known $C$. pepo ssp. ovifera var. ozarkana and var. texana geographic distributions (Decker, 1988; Smith et al., 1992), and through consultation with Dr. Bruce Smith (Smithsonian Institution, Washington, DC), who subsequently took part in the 2000 survey. Sampling locations were recorded using a Magellan 315 global positioning system (GPS) receiver (Magellan Navigation, Inc., San Dimas, CA). GPS coordinates were validated with Google Earth (http://earth. google.com/), and are available upon request. A cluster sampling strategy was used to sample for virus incidence at each location. In cluster sampling, each sampling unit contains $n$ individuals, and all sampled individuals are assayed. There is no requirement that $n$ is identical in each sampling unit (Madden and Hughes, 1999). This strategy is especially suited for populations of free-living C. pepo, which are extremely variable in size.

Population counts and samples for ELISA were collected from late July through September of each year (with the exception of two populations that were surveyed and sampled in late June, 2000). This timeframe was based on previous records and consultations with local experts, which led to the conclusion that the typical growing season was May through November. Therefore, the surveys were conducted during the middle months of the growing season. Only individuals that were clearly established were counted and sampled for ELISA.
The furthest reported incidence of pollen-mediated gene flow between free-living C. pepo plants is $1300 \mathrm{me-}$ ters (Kirkpatrick and Wilson, 1988). Thus, when sampling spatially distinct plant groups in a survey area in our study, groups of individuals within $2 \mathrm{~km}$ of each other were arbitrarily regarded as belonging to the same population since there was potential for gene exchange via pollen. We recognize that this classification does not take into consideration gene flow via seeds.

In our study, population size estimates were accurate to within 5,10 , and 50 plants for populations possessing up to 50,100 , and 300 plants, respectively. When plant numbers were sufficiently low and individuals could be sufficiently separated to allow accurate counts, all individuals were counted. Nevertheless, the precision of populations $>300$ plants could not be rigorously established.

Plants were scored visually as being either symptomatic or asymptomatic, without quantifying the severity of symptoms. Because there is no reliable method of distinguishing between viruses based on symptoms, especially when there are mixed infections, we also did not classify infection by different viruses based on symptoms.

\section{ELISA assays}

Leaves for ELISA assays were sampled from randomly chosen plants, without regard to symptoms. Because of high variability in the number of plants in each population, and varying degrees of separation between plants in a population, it was not possible to predetermine either a specific sampling pattern, or a threshold representative number. However, in most populations of up to 25 individuals, each individual was sampled. Voucher specimens of some populations were collected, pressed, and archived (Herbarium of the Department of Biological Sciences, Western Michigan University, Kalamazoo, Michigan, USA).

ELISA assays for CMV, general potyvirus, ZYMV, WMV2, and PRSV were conducted using commercial kits, using protocols supplied by the manufacturer (Agdia, Elkhart, IN). Samples were initially assayed with the CMV kit, and then with the general potyvirus assay. To determine the spectrum of virus infection, samples that scored positive in the general potyvirus screen were subsequently assayed for the presence of ZYMV, WMV2, and PRSV. Thresholds for distinguishing positive from negative reactions were those established by Frey et al. (1998). Data analyses were performed using GraphPad Prism version 5.0a for Mac OS X, GraphPad Software, San Diego, California, USA, www.graphpad.com. 


\section{H. Quemada et al.}

\section{ACKNOWLEDGEMENTS}

This project was supported by the Biotechnology Risk Assessment Research Grants (BRAG) program of the USDA Cooperative State Research, Education, and Extension Service (CSREES) through a grant, "Gene Flow from Transgenic Cucurbita pepo into 'Free-living' populations".

Received August 11, 2008; accepted October 2nd, 2008.

\section{REFERENCES}

Arias DM, Rieseberg LH (1994) Gene flow between cultivated and wild sunflower. Theor. Appl. Genet. 89: 655-660

Boyette G, Templeton E, Oliver LR (1984) Texas gourd (Cucurbita texana) control. Weed Science 32: 649-655

Bridges DC (1992) Crop Losses Due to Weeds in Canada and the United States. Bridges DC, ed, Champaign, IL, Weed Science Society of America

Brookes G, Barfoot P (2005) GM crops: the global economic and environmental impact - the first nine years 1996-2004. AgBioForum 8: 187-196

Brookes G, Barfoot P (2006) Global impact of biotech crops: Socio-economic and environmental effects in the first ten years of commercial use. AgBioForum 9: 138-151

Burke JM, Rieseberg LH (2003) Fitness effects of transgenic disease resistance in sunflowers. Science 300: 1250

Chung SM, Decker-Walters DS, Staub JE (2006) Cultivarto-wild population introgression in Cucurbita pepo subsp. ovifera. J. New Seeds 8: 1-18

Decker DS (1988) Origin(s), evolution, and systematics of Cucurbita pepo (Cucurbitaceae). Econ. Botany 42: 4-15

Decker-Walters DS, Walters TW, Cowan CW, Smith BD (1993) Isozymic characterization of wild populations of Cucurbita pepo. J. Ethnobiol. 13: 55-72

Decker-Walters DS, Staub JE, Chung S-M, Nakata E, Quemada HD (2002) Diversity in free-living populations of Cucurbita pepo (Cucurbitaceae) as assessed by random amplified polymorphic DNA. Syst. Botany 27: 19-28

Frey A, Di Canzio J, Zurakowski D (1998) A statistically defined endpoint titer determination method for immunoassays. J. Immunol. Methods 221: 35-41

Fuchs M, Chirco EM, Gonsalves D (2004a) Movement of coat protein genes from a commercial virus-resistant transgenic squash into a wild relative. Environ. Biosafety Res. 3: 5-16

Fuchs M, Chirco EM, McFerson J, Gonsalves D (2004b) Comparative fitness of a wild squash species and three generations of hybrids between wild $\mathrm{X}$ virus-resistant transgenic squash. Environ. Biosafety Res. 3: 17-28

Hancock J (2003) A framework for assessing the risk of transgenic crops. BioScience 53: 512-519
Kirkpatrick KJ, Wilson HD (1988) Interspecific gene flow in Cucurbita: C. texana vs. C. pepo. Am. J. Bot. 75: 519-527

Klas F, Fuchs M, Gonsalves D (2006) Comparative spatial spread overtime of Zucchini Yellow Mosaic Virus (ZYMV) and Watermelon Mosaic Virus (WMV) in fields of transgenic squash expressing the coat protein genes of ZYMV and WMV, and in fields of nontransgenic squash. Transgenic Res. 15: $527-541$

Kuti JO, Moline HR (1986) Effects of inoculation with a mild strain of tomato aspermy virus on the growth and yield of tomatoes and the potential for cross protection. $J$. Phytopathol. 115: 56-60

Linder CR, Taha I, Seiler G, Snow A, Rieseberg L (1998) Long-term introgression of crop genes into wild sunflower populations. Theor. Appl. Genet. 96: 339-347

Madden LV, Hughes G (1999) Sampling for plant disease incidence. Phytopathology 89: 1088-1103

Pallet DW, Milou IT, Edwards M, Naylor M, Wang H, Alexander M, Gray AJ, Mitchell E, Raybould A, Walsh JA, Cooper JI (2004) A tiered approach to risk assessment of virus resistance traits based on studies with wild Brassicas in England. In den Nijs HCM, Bartsch D, Sweet J, eds, Introgression from Genetically Modified Plants Into Wild Relatives, pp 309-322

Perring TM, Farrar CA, Blua MJ, Wang HL, Gonsalves D (1995) Cross protection of cantaloupe with a mild strain of zucchini yellow mosaic virus: effectiveness and application. Crop Prot. 14: 601-606

Pilson D (2000) Herbivory and natural selection on flowering phenology in wild sunflower, Helianthus annuus. Oecologia 122: $72-82$

Pilson D, Decker KL (2002) Compensation for herbivory in wild sunflower: response to simulated damage by the headclipping weevil. Ecology 83: 3097-3107

Raybould A, Cooper I (2005) Tiered tests to assess the environmental risk of fitness changes in hybrids between transgenic crops and wild relatives: the example of virus resistant Brassica napus. Environ. Biosafety Res. 4: 127-140

Reagon M, Snow AA (2006) Cultivated Helianthus annuus (Asteraceae) as a genetic "bridge" to weedy sunflower populations in North America. Am. J. Bot. 93: 127-133

Rieseberg LH, Kim MJ, Seiler GJ (1999) Introgression between cultivated sunflowers and a sympatric wild relative, Helianthus petiolaris (Asteraceae). Int. J. Plant Sci. 160: 102108

Sankula S (2006) Quantification of the impacts on US agriculture of biotechnology-derived crops planted in 2005. National Center for Food and Agricultural Policy, Washington, D.C.

Sankula S, Blumenthal E (2004) Impacts on US agriculture of biotechnology-derived crops planted in 2003 - an update of eleven case studies. National Center for Food and Agricultural Policy, Washington, D.C.

Smith BD, Cowan CW, Hoffman MP (1992) Is it an indigene or a foreigner? In Smith BD, ed, Rivers of change: essays 
on the origins of agriculture in eastern North America. Smithsonian Institution Press, Washington, D.C., pp 67-100

Snow AA, Moran-Palma P, Rieseberg LH, Wszelaki A, Seiler GJ (1998) Fecundity, phenology, and seed of F1 wildcrop hybrids in sunflower (Helianthus annuus, Asteraceae). Am. J. Bot. 85: 794-801

Snow AA, Pilson D, Rieseberg LH, Paulsen MJ, Pleskac N, Reagon MR, Wolf DE, Selbo SM (2003) A Bt Transgene reduces herbivory and enhances fecundity in wild sunflowers. Ecol. Appl. 13: 279-286

Spence NJ, Mead A, Miller A, Shaw ED, Walkey DGA (1996) The effect on yield in courgette and marrow of the mild strain of zucchini yellow mosaic virus used for crossprotection. Ann. Appl. Biol. 129: 247-259

Spencer LJ, Snow AA (2001) Fecundity of transgenic wildcrop hybrids of Cucurbita pepo (Cucurbitaceae): implications for crop to wild gene flow. Heredity 86: 694-702

US National Research Council (2000) Genetically modified pest-protected plants: science and regulation. National Academy Press, Washington DC

US National Research Council (2002) Environmental effects of transgenic plants: the scope and adequacy of regulation. National Academy Press, Washington DC

USDA (1994a) Availalability of determination of nonregulated status for virus resistant squash. Federal Register 59: 6418764189

USDA (1994b) APHIS/USDA Petition 92-204-01 for determination of nonregulated status for ZW-20 squash. Environmental Assessment and Finding of No Significant Impact. $\quad$ http://www.aphis.usda.gov/brs/aphisdocs2/92_ 20401p_com.pdf

USDA (1994c) USDA/APHIS Petition P93-106-01 for Determination That $\mathrm{BXN}^{\mathrm{TM}}$ Cotton Poses No Plant Pest Risk. Environmental Assessment February 1994. Finding of No Significant Impact (FONSI) for Nonregulatory Status of $\mathrm{BXN}^{\mathrm{TM}}$ Cotton, Calgene Petition P93-1096-01. http://www. aphis.usda.gov/brs/aphisdocs2/93_19601p_com.pdf

USDA (1994d) Response to Calgene Petition 94-090-01p for Determination of Nonregulated Status for Laurate Canola Lines. Environmental Assessment and Finding of No Significant Impact. http://www.aphis.usda.gov/brs/ aphisdocs2/94_09001p_com.pdf

USDA (1995a) Monsanto Petition 95-045-01p to USDA/APHIS for Determination of Nonregulated Status of Glyphosate Tolerant Cotton (Roundup Ready $\left.{ }^{\mathrm{TM}}\right)$. Environmental Assessment and Finding of No Significant Impact. http://www.aphis.usda.gov/brs/ aphisdocs2/95_04501p_com.pdf

USDA (1995b) USDA/APHIS Determination on a Petition 94-308-01p of Monsanto Agricultural Company Seeking Nonregulated Status of Lepidopteran-resistant Cotton Lines 531, 757, 1076. Environmental Assessment and Finding of No Significant Impact. http://www.aphis.usda.gov/brs/ aphisdocs2/94_30801p_com.pdf
USDA (1996a) Asgrow Seed Company: Availability of Determination of Nonregulated Status for Squash Line Genetically Engineered for Virus Resistance. Federal Register 61: 33484-33485

USDA (1996b) USDA/APHIS Petition 95-352-01p for Determination of Nonregulated Status for CZW-3 Squash. Environmental Assessment and Finding of No Significant Impact. http://www.aphis.usda.gov/brs/aphisdocs2/95_ 35201p_com.pdf

USDA (1996c) Dupont Petition 95-256-01p to USDA/APHIS for Determination of Nonregulated Status of Sulfonylurea Tolerant Cotton Line 19-51a. Environmental Assessment and Finding of No Significant Impact. http://www.aphis.usda.gov/ brs/aphisdocs2/95_25601p_com.pdf

USDA (1997a) USDA/APHIS Petition 97-013-01p for Determination of Nonregulated Status for Events 31807 and 31808 Cotton. Environmental Assessment and Finding of No Significant Impact. http://www.aphis.usda.gov/brs/ aphisdocs2/97_01301p_com.pdf

USDA (1997b) USDA/APHIS Petition 97-013-01p for Determination of Nonregulated Status for Events 310807 and 31808 Cotton. Evironmental Assessment and Finding of No Significant Impact. http://www.aphis.usda.gov/brs/ aphisdocs2/97_01301p_com.pdf

USDA (1998a) AgrEvo USA Company Petition 98-329-01p. Determination of Nonregulated Status for Glufosinate Tolerant Rice Transformation Events LLRICE06 and LLRICE62. Finding of No Significant Impact. http://www. aphis.usda.gov/brs/aphisdocs2/98_32901p_com.pdf

USDA (1998b) Response to AgrEvo Petition 97-205-01p for Determination of Nonregulated Status for Glufosinate Tolerant Canola. Environmental Assessment and Finding of No Significant Impact. http://www.aphis.usda.gov/brs/ aphisdocs2/97_20501p_com.pdf

USDA (1999a) Response to AgrEvo Petition 98-278-01p for Determination of Nonregulated Status for Canola Transformation Events MS8 and RF3 Genetically Engineered for Pollination Control and Tolerance to Glufosinate Herbicide. Finding of No Significant Impact.

USDA (1999b) Response to Monsanto Petition 98-216-01p for Determination of Nonregulated Status for GlyphosateTolerant Canola Line RT73. Environmental Assessment and Finding of No Significant Impact. http://www.aphis.usda.gov/ brs/aphisdocs2/98_21601p_com.pdf

USDA (2002a) Approval of Monsanto Company Petition (00342-01p) Seeking a Determination of Nonregulated Status for Bollgard II Cotton Event 15985 Producing the Cry $2 \mathrm{Ab}$ Insect Control Protein Derived from Bacillus thuringiensis subsp. Kurstaki. Environmental Assessment and Finding of No Significant Impact. http://www.aphis.usda.gov/brs/ aphisdocs2/00_34201p_com.pdf

USDA (2002b) USDA/APHIS Decision on Monsanto Company Request (01-324-01p) Seeking an Extension of Determination of Nonregulated Status for Glyphosate Tolerant Canola Event GT200. Finding of No Significant Impact. http://www.aphis. usda.gov/brs/aphisdocs2/01_32401p_com.pdf 


\section{H. Quemada et al.}

USDA (2002c) Approval of Aventis CropScience USA LP (01-206-01p) Seeking Extension of Determination of Nonregulated Status for Male Sterile, Fertility Restoration, Glufosinate Tolerant Canola Transformation MS1 and RF1/RF2. Finding of No Significant Impact. http://www. aphis.usda.gov/brs/aphisdocs2/01_20601p_com.pdf

USDA (2002d) USDA/APHIS Decision on Aventis CropScience USA LP Request (01-206-02p) Seeking and Extension of Determination of Nonregulated Status for Glufosinate Tolerant Canola Event Topas 19/2. Finding of No Significant Impact. http://www.aphis.usda.gov/brs/ aphisdocs2/01_20602p_com.pdf

USDA (2003) Approval of Aventis CropScience USA LP Petition (02-042-01p) Seeking a Determination of Nonregulated Status for Glufosinate-ammonium Herbicidetolerant Cotton Transformation Event LLCotton25. http:// www.aphis.usda.gov/brs/aphisdocs2/02_04201p_com.pdf

USDA (2004a) Approval of Monsanto Company Request (04086-01p) Seeking a Determination of Non-regulated Status for Glyphosate Tolerant Cotton Event MON 88913. http:// www.aphis.usda.gov/brs/aphisdocs2/04_08601p_com.pdf
USDA (2004b) Approval of Mycogen/Dow Petitions 03-03601p and 03-036-02p Seeking Determination of Nonregulated Status for Insect-Resistant Cotton Events 281-24-236 and 3006-210-23 Genetically Engineered to Express Synthetic B.t. Cry1F and Cry1Ac, Respectively. Environmental Assessment and Finding of No Significant Impact. http:// www.aphis.usda.gov/ brs/aphisdocs2/03_03601p_com.pdf

USDA (2005) Syngenta Petition 03-155-01p for Determination of Nonregulated Status for Lepidopteran Resistant Cotton Event COT102. USDA/APHIS Environmental Assessment and Finding of No Significant Impact. http://www.aphis.usda. gov/brs/aphisdocs2/03_15501p_com.pdf

USDA (2006) Finding of No Significant Impact. Animal Plant Health Inspection Service. Extension of Nonregulated Status to Rice Line LLRICE601. http://www.aphis.usda.gov/brs/ aphisdocs2/06_23401p_com.pdf.

Whitton JD, Wolf E, Arias DM, Snow AA, Rieseberg LL (1997) The persistence of cultivar alleles in wild populations of sunflowers five generations after hybridization. Theor. Appl. Genet. 95: 33-40

Wilson HD (1990) Gene flow in squash species. BioScience 40: 449-455 